\title{
The (Mis)Use of Disaster as Opportunity: Coerced Relocation from Celaque National Park, Honduras
}

\author{
Benjamin F. Timms \\ Social Sciences Department, California Polytechnic State University, \\ San Luis Obispo, CA, USA; \\ btimms@calpoly.edu
}

\begin{abstract}
Disaster capitalism" refers to political economic processes that take advantage of mass trauma to impose neoliberal capitalist economic policies, facilitating the redistribution of wealth and exacerbating socio-economic divisions. Here the basic tenets of disaster capitalism are applied in another context: how natural disasters can be used to impose exclusionary protected area conservation principles with similar socio-economic consequences and ecological ramifications. The postHurricane Mitch relocation of resident populations from Celaque National Park, Honduras serves as a case study whereby a natural disaster, combined with the effects of neoliberal structural adjustment policies, created the opportunity to implement a universal model of exclusionary nature protection. The resultant displacement and increased semi-proletarianization of the affected population effectively served the capitalist interests of international conservation and the agro-export coffee industry and, contradictorily, worked against the proclaimed goals of nature preservation through exclusionary national park policies.
\end{abstract}

Keywords: Central America, Honduras, protected areas, political ecology, disaster capitalism, relocation

\section{Introduction}

In October 1998 Hurricane Mitch, one of the most destructive natural disasters to strike Central America in recorded history, stalled over the region causing widespread flooding and landslides 
killing an estimated 11,000 people (NACLA 1999:10). In Honduras at least 5600 people died and 285,000 were left homeless as the natural disaster altered the physical and social landscapes of the nation (Lehmann 2001). The devastating effects were felt throughout the country, even in areas far inland from the Caribbean Sea where Hurricane Mitch originated.

In the western highlands of Honduras the small-farming peasant communities within Celaque National Park suffered from crop failures, waterlogged soils, landslides, and swelled rivers that swept away homes, cattle, and people. With much of the population huddled together in shelters and suffering from gastrointestinal illnesses and hunger, a contingent of residents was sent to the local municipality to solicit immediate assistance in the form of food and medicine and, in the long term, the rebuilding of their communities (Oviedo 1999). The municipality, Catholic Church, and the non-governmental organizations (NGOs) Proyecto Celaque and Amigos de las Am'ericas responded by building two new settlements on the outskirts of the park for affected households.

In light of such devastation, assistance provided to survivors is commonly welcomed as altruistically beneficial. However, assistance predicated on conditions can be critically interpreted through the lens of what Naomi Klein (2007) termed “disaster capitalism”, which explains how postdisaster reconstruction has been used to implement neoliberal capitalist economic policies that redistribute wealth and exacerbate socio-economic divisions. A pointed example is the privatization and profiteering that occurred during the reconstruction efforts for Hurricane Katrina whereby the United States government was complicit in advancing capitalist corporate interests at the expense of a large section of the affected populace which were, or became, "disposable” (Giroux 2006). In this article the basic tenets of "disaster capitalism" are adopted in another context; to analyze how conditional aid was used to coercively implement another set of principles serving capitalist 
interests—namely exclusionary protected area policies—with negative socio-economic and ecological repercussions.

The post-Hurricane Mitch relocation of residents from Celaque National Park, Honduras is presented as a case study of this process. Honduras, with a heavy international debt load, implemented neoliberal structural adjustment policies during the 1990s that retracted state spending and power while, simultaneously, required environmental programs including a formalized protected area system (Jansen 1998; Richards 1996; Schelhas and Pfeffer 2008; Schulz and Schulz 1994). To rectify the lack of funding for such initiatives, non-state entities were legally allowed to take charge of protected area management (Beltr'an and Esser 1999). For Celaque National Park the NGO Proyecto Celaque, created by the German development agency GTZ in 1997, was given the task of crafting and executing a management plan that included the stated goal of "encouraging" the depopulation of the park (AFECOHEDEFOR, GTZ and GFA TERRA Systems 2002).

Within a year of the founding of Proyecto Celaque, the devastation of Hurricane Mitch provided the opportunity to coercively implement this policy through conditional aid that resulted in the displacement, impoverishment, and increased semi-proletarianization of half the park's inhabitants who "accepted" relocation. These conditions initially served the stated interests of nature protection while contributing to the funding objectives of GTZ. But ultimately relocation benefited the cheaplabor interests of the agro-export coffee industry through the dispossession and impoverishment of peasant households relocated from Celaque National Park who significantly increased labor services for the coffee industry while accepting lower wages, with additional negative ecological consequences (Timms 2007).

While the proximate cause of relocation was a natural disaster, the ultimate cause was the coercive implementation of a national park model based on the exclusion of human occupation. 
Here post-Hurricane Mitch relocation will be interpreted through the lens of disaster capitalism which investigates the use of "moments of collective trauma to engage in radical social and economic engineering” (Klein 2007:9). As this paper covers both disasters and conservation, it begins with a review of disaster capitalism followed by an assessment of the coercive legacy of exclusionary nature protection. It then provides a political ecology analysis of Celaque National Park and presents empirical research on the livelihood alterations created by relocation from the park that is, in the subsequent section, interpreted from the disaster capitalism framework. The results support a return to the interests of those impacted by disaster reconstruction in composing more humane and less opportunistic reconstruction efforts.

\section{Disaster Recovery or Disaster as Opportunity?}

The study of natural disasters has long been an important topic of inquiry, both in relation to prevention and recovery (Oliver-Smith 1986; White 1974). These natural events are considered disturbances and part of the natural order from an ecological perspective (Reice 2003). However, when vulnerable human populations are detrimentally impacted they become social, economic, and physical disasters. Appropriate recovery after such natural disasters as floods, volcanic eruptions, earthquakes, and hurricanes should focus on restoring the livelihoods of victims and making them less vulnerable and more resilient to future events (Lewis 1999; Wisner et al 2003). In order to do so it must be acknowledged that it is not just the initial natural event that causes the disaster, there are social and economic processes that cumulatively create vulnerability.

For example, while Hurricane Mitch arrived in Central America in October 1998, the conditions for a natural disaster had already been set in the previous century as the agro-export banana, coffee, beef, and cotton industries appropriated vast amounts of fertile lands in the region, forcing impoverished rural populations onto steep degraded slopes that were vulnerable to landslides and 
flooding (Comfort et al 1999; Stonich 2008). More recently, the debt crisis of the 1980s and associated neoliberal capitalist restructuring in the 1990s led to structural adjustment policies that weakened states fiscally and institutionally, further exacerbating the vulnerability of populations and hindering the ability of states to respond to disasters and support reconstruction (Russell 1999). To fill this void, international aid agencies, NGOs, and even private corporations were promoted as decentralized agents better able to deliver appropriate local recovery as they are either more attuned to local priorities and needs, as in the case of local NGOs (Agrawal and Gibson 1999), or motivated by a profit motive absent from state bureaucracies.

However, the tragedy of negligence that resulted from such decentralization in the response to Hurricane Katrina has spawned new avenues of research that more explicitly link political economy with natural disasters (Powers 2006); notably Naomi Klein’s concept of “disaster capitalism,” which seeks to understand how disaster reconstruction can be used as an opportunity to implement neoliberal capitalist economic policies that redistribute wealth and exacerbate socio-economic divisions; "I call these orchestrated raids on the public sphere in the wake of catastrophic events, combined with the treatment of disasters as exciting market opportunities, 'disaster capitalism”” (Klein 2007:6). Schuller (2008) elaborates on three interrelated components of disaster capitalism: the increasing role of private institutions in public responses to disasters; the promotion of neoliberal capitalist policies in the process; and the instrumental use of catastrophes as opportunities to do so. As mentioned, of particular interest is the retrenchment of state power in public service provision championed by neoliberalism, which has been widely unpopular in many parts of the global South and, in some cases, has led to popular uprisings (Harvey 2005).

Yet the jolt provided by disasters can create opportunity to circumvent such popular discord through shocking populations into a state of disorientation, leaving them vulnerable to the 
imposition of neoliberal economic policies that previously would have been unacceptable. Klein (2007) uses political shocks, such as the assassination of Allende in Chile and the recent war in Iraq, along with natural disasters like Katrina, to exemplify disaster capitalism. In turn, Klein has inspired further analysis of disaster capitalism, such as post-tsunami reconstruction in Sri Lanka whereby local artisanal fishing communities were barred from rebuilding within $100 \mathrm{~m}$ of the ocean in the name of reducing vulnerability while, contradictorily, allowing hotel construction to continue within the same buffer zone (Gunewardena 2008). In essence, it thwarted local livelihoods and removed resistance toward tourism development, which promoted the capitalist interests of the latter. Similarly, the focus of disaster recovery on the tourism industry in Honduras after Hurricane Mitch failed to address the underlying socioeconomic processes that had created vulnerability for the impoverished and heavily impacted populace in the country, leaving them less resilient to withstand future natural disasters (Comfort et al 1999; Morris and Wodon 2003; Stonich 2008). What they all share in common is the use of disaster as an opportunity to promote capitalist interests at the expense of sufficient and equitable disaster reconstruction.

What is of utmost interest in this article is the displacement of populations resulting from natural disasters. Temporary relocation of populations in the aftermath of a disaster can be used to facilitate immediate provision of aid while permanent relocation can reduce future geographic vulnerability by removing populations from hazardous areas, such as floodplains or degraded hillsides. However, relocation should be a strategy of last resort as "[i]nduced, coercecd, forced, or spontaneous population movements have frequently been a direct cause of vulnerability, removing people from their accustomed resource base and creating conditions of dependency, which exacerbates disaster and which disaster exacerbates” (Lewis 1999:16). Further, as argued in this article, relocation after a 
disaster to serve ulterior motives that promote the accumulation of capital by some at the expense of victims' livelihoods exhibits the true cost of disaster capitalism.

\section{Conservation and Capitalism}

In this article the same theoretical approach is applied in a more supposedly benign topicnamely nature preservation. While the preservation of nature appears to be at odds with capitalist ideologies, especially when compared to post-disaster reconstruction efforts, it has been theorized as contributing to the evolution of capitalism through transferring communal or state control over resources to private interests, in effect serving as a new round of primitive accumulation whereby displaced populations are brought into capitalist relations of production as a proletariat, or semiproletariat, workforce (Katz 1998; Peluso and Watts 2001). Further, preserved nature itself has been reworked during the neoliberal era into a fetish commodity for tourists to aesthetically consume, corporations to promote for public relation campaigns, and international conservation organizations to effectively sell through fundraising activities (Carrier and Macleod 2005; Dowie 2009; Igoe and Brockington 2007; Tsing 2005). As Brockington, Duffy and Igoe (2008) illustrate, the rapid expansion of protected areas in the 1980s and 1990s occurred alongside the global growth of tourism and the ascendance of neoliberal capitalism, which they demonstrate was not just a convenient coincidence.

However, the antecedents to modern "neoliberal conservation” (Igoe and Brockington 2007:432) stretch back to the origins of capitalism itself. The claiming of forests in medieval Europe for elite game parks and the Enclosure Act of the Tudors exhibit the shift from common property to state and private property, which is one of the original forms of primitive accumulation whereby land become a commodity and the displaced a landless proletarian labor force (Cosgrove 1985;

Neumann 1998). Similarly, during the colonial era, expanding European states acquired control 
over natural resources at the global scale, with the first formal forest reservations created to protect soil resources on Caribbean plantation islands in order to maintain their economic contributions toward these emerging capitalist European states (Grove 1995).

The nineteenth-century manifestation of national parks in the United States also served the interests of capital, namely railroad corporations and associated tourist concessionaires that profited handsomely from their creation (Brockington, Duffy and Igoe 2008; Schelhas and Pfeffer 2008). While naturalists such as John Muir are commonly credited with the idea of national parks, they also allied themselves with the railroad companies and wealthy philanthropists in lobbying for national park creation (Dowie 2009; Tsing 2005). Even the design of these "natural" parks had their origins in the landscape architecture of Frederick Law Olmstead's urban parks, which served as spaces for recreation for the populace while creating capitalist economic benefit out the recuperation of labor (Carr 1998; Grusin 1998; Neumann 1998).

Appropriation of these areas of nature for preservation and tourism relied on exclusion whereby "the reservation of 'nature' required and facilitated reservations for various Native nations" (Germic 2001:9). From Yellowstone to Yosemite, and the Grand Canyon to Glacier, these American national parks turned local livelihoods into criminal acts that resulted in evictions and loss of resource access in attempts at “civilizing” Native American populations through separating them from nature and bringing them into the mainstream market economy as sources of cheap labor (Burnham 2000; Jacoby 2001). In addition to those displaced, the National Park Service in Yosemite and Grand Canyon allowed small populations of Native Americans to remain as labor for maintenance and tourist concessionaires, which created a captive labor force that was kept impoverished through underemployment (Spence 1999). The dual outcome of appropriating 
property for capitalist profit making and the extraction of surplus labor value of the dispossessed is a classic form of primitive accumulation.

The creation of national parks was also deeply imbedded in the expansion of power and control of the United States government and market economy into frontier territories at the margin of the state's sphere of influence (Patin 1999; Smethurst 2000). More recently, and from a global perspective, the ideal location to implement contemporary strategies of nature conservation has been in the economically less developed regions of the world where relatively more abundant areas have yet to be formally protected (Michael 1995). The result has been an exponential growth of formal areas to "protect" nature from a mere 1000 in 1962 to over 100,000 in 2003, covering close to $12 \%$ of the earth's terrestrial surface (Chape et al 2003). Of the six IUCN categories for protected areas, $23.6 \%$ of the total area covered is comprised of national parks which include within their management objectives the stated goal "to eliminate and thereafter prevent exploitation or occupation” (Davey 1998:52).

Local populations, often comprising the rural poor with little political or economic power, are asymmetrically impacted by protected area policies (Wilshusen et al 2002). Hegemonic discourse over the environment has often made marginalized populations on the global periphery scapegoats for environmental degradation (Escobar 1995). Such discourse is realized in the exclusionary objectives of national parks, and their establishment has often resulted in the dispossession and relocation of residents (Brockington and Igoe 2006; Brockington, Igoe and Schmidt-Soltau 2006; Neumann 1998) which effectively transfers the ownership of resource rich but marginally located landscapes from local people to global conservation organizations (Smethurst 2000). 
The global diffusion of protected areas, and in particular national parks, is the result of processes and actors at multiple scales interacting and reflecting unequal power relations, from the local to the global. One influential group of actors, international conservation organizations, have become significant global vehicles for nature accumulation which Katz describes as "a whole new regime of imperial exploitation camouflaged as environmentalism. There is big money to be made from 'preserving' nature, and the current transnational political ecological relations by and large ensure that the eventual profits will flow North” (1998:50). And today the motive for this accumulation of nature can be extended beyond conservation to scientific study, pharmaceutical interests, ecotourism, payments for ecosystem services, and even the attraction of foreign aid (Brockington, Duffy and Igoe 2008; Carrier and Macleod 2005; Katz 1998; Stonich 2008).

The creation of protected areas serves the financial interests of international conservation organizations whose funding is tied to the meeting of donors agendas (Bebbington 2004; Chapin 2004; Romero and Andrade 2004). Major funding sources include aid agencies such as the Global Environmental Facility (GEF), World Bank, USAID, and the European Commission, which together provided \$8 billion for conservation related projects in 2004 alone (Dowie 2009:52). In addition, international conservation agencies also receive substantial financial support from corporate sponsors as nature protection becomes increasingly tied to serving the interests of capital accumulation.

Brockington, Duffy and Igoe (2008) identify the reworking of nature protection into new commodities through applying Marx's conception of fetishization where value inherent in a commodity is created that is not dependent on labor value. In doing so it further separates the consumer from the product by hiding the social and ecological relations that are responsible for the production of the commodity. For example, eco-tourism in national parks is sold to the tourist 
as an image of a pristine nature without human impact, which conveniently omits the displacement and resultant socio-economic repercussions resultant from national park creation (Carrier and Macleod 2005; Timms 2008). Corporations also take advantage of fetishization by financing conservation organizations in exchange for certifications that give the public the image of good environmental governance that obscures their environmentally and socially damaging activities in other locations (Tsing 2005). International conservation organizations receive value from protected areas through promoting their creation in fundraising activities. This modern reworking of the environment into a "spectacle of Nature" exhibits the modern neoliberal ties between capitalism and nature conservation (Brockington, Duffy and Igoe 2008:76).

The preceding discussion has exhibited how nature protection serves capitalists' interests through fetishized commodities and primitive accumulation which creates value for conservation organizations, the tourism industry, and corporate sponsors at the expense of the dispossessed. This is not to say that impoverished local populations are passive victims to eviction and exploitation; when faced with dispossession and further pauperization they employ what power and weapons they have at their disposal to resist (Scott 1985). But, as elaborated by disaster capitalism, there are social, economic, and environmental shocks that leave populations too vulnerable and disoriented to oppose relocation from protected areas.

One powerful shock, particularly at the state level, has been the debt crisis for developing countries (Harvey 2005). While perhaps more subtle in the short term than warfare or natural disasters, the debt crisis over the long term has been the main instrument for the imposition of neoliberal economic restructuring by global lending agencies, such as the IMF and World Bank, that have undermined state power to govern territory due to fiscal cuts in government spending while liberalizing trade policies. Paradoxically, international conservation organizations have influenced international 
lending agencies and aid institutions to attach conditions on loans and aid packages to include global conservation programs such as protected area creation (Katz 1998); and yet the conditioned fiscal restraints deny state funding for such initiatives. To solve this contradiction, and in the name of “decentralization” (Zimmerer 2006), international conservation organizations are given increased access to fund and manage protected areas, effectively eroding the role of the state and increasing international and/or private control over state territory, effectively promoting what has been termed “privatized sovereignty” (Mbembe 2001).

The argument for decentralization claims that states are inefficient or incapable of implementing conservation at the local level (Igoe and Brockington 2007). Communities, having an intimate stake and being geographically proximate to the natural resource base, are considered better able to democratically implement conservation strategies (Agrawal and Gibson 1999). Social scientists have long advocated empowering communities in conservation and development decision-making and management (Conway and Timms 2003; Ostrom 1990). To their credit, conservation organizations have responded to these calls for decentralization by partnering with local NGOs (Krueger 2009), particularly due to requirements from international funding agencies that promote NGO development to fill in the roles abandoned by fiscally weakened states.

For democratic decentralization to be realized, the state and conservation organizations have to abdicate power in order to empower local communities (Agrawal and Gibson 1999; Brockington, Duffy and Igoe 2008). However, decentralization to local communities has often been illusory as power has devolved from the state to NGOs, which are not necessarily accountable to local populations. In this regard local populations can actually be disempowered by decentralization, which amounts to a "democracy-wash" if proxy NGOs are created and funded by international 
conservation organizations to implement their conservation agendas, bypassing local decisionmaking. It is imperative that local NGOs continue to develop true community participation in conservation activities if decentralization is to deliver on its promise of participatory democracy (Ribot 2004).

In the following section the case of Celaque National Park serves as a representative example of how the shock of a structural adjustment program allowed the misuse of the concept of decentralization to facilitate the penetration of a national park model based on human exclusion into the western highlands of Honduras. However, the actual implementation of exclusionary policies required the massive "natural" shock of Hurricane Mitch to become operational. The resultant socioeconomic and ecological repercussions on relocated Lencan peasant households served the cheap labor interests of the agro-export coffee industry while also creating fetishized value for a foreign development agency, GTZ, through a "successful" implementation of an exclusionary national park project.

\section{The Political Ecology of Celaque National Park}

Celaque National Park, located in the western highlands of Honduras near the border with Guatemala and El Salvador, is noted as the source for dozens of rivers that provide the water supply for over 100 surrounding communities (AFE-COHEDEFOR, GTZ and GFA TERRA Systems 2002). In addition to the ecological service of water provision, the unique assemblage of flora and fauna constitutes high biological diversity in the largest montane moist forest in Honduras (IUCN 2009). More commonly referred to as cloud forests, they are considered to be among the most threatened ecological systems in the world, making their preservation a high priority (WCMC 1998). 
While the value of conserving the Celaque Mountains is evident in its important assemblage of biological diversity and ecological services, it is also a cultural landscape with a history of human habitation (Timms 2008). Existing within the park are several settlements lying on the margins of the cloud forest and populated by indigenous Lenca peasant households (AFE-COHEDEFOR, GTZ and GFA TERRA Systems 2002). The households rely primarily on subsistence agriculture for their livelihoods, using a swidden fallow system to grow the traditional milpa crops of corn and beans along with cool weather crops such as cabbage, potatoes, and carrots (Brady 2003; Jansen 1998). Income-generating activities are used to supplement livelihoods through the sale of surplus crops and ceramic crafts at lowland markets, and engaging in seasonal labor on down-slope coffee fincas (Timms 2007).

Settlement patterns and livelihood strategies in the western highlands of Honduras exhibit semisubsistence peasant households in the higher reaches of the mountains with ladino farms and commercial coffeefincas encroaching from below (Cherrett 2001; Stonich 1993; West 1958). This pattern has evolved over the past 400 years in relation to commodity cycles. During growth periods in Honduran mineral exports valuable land concessions were granted to mining companies (Finney 1978), many of which resulted in forced relocations of Lencan communities to reducciones in order to serve as cheap labor for capitalist mining interests (Newson 1982; Petras and Veltmeyer 2002; Stonich 1993). During downturns in the commodity cycle, when labor was no longer required, the Lenca drifted back into the remote mountainous highlands and formed the semi-proletariat peasantry (Brockett 1991). While the Lenca have lived in the Celaque Mountains from at least the time of Spanish settlement of the area in 1536 (Newson 1982), interviews during fieldwork indicated local knowledge of continuous settlement within the mountains from only around 1900. 
This timeframe has been reported in other parts of the western highlands of Honduras (Jansen 1998; Stonich 1993) and, interestingly, corresponds with a collapse in the export of Honduran silver.

It was not until after the Great Depression that the coffee industry in Honduras expanded rapidly with its highland ecological niche placing it in direct competition for land with the semisubsistence peasantry (Faber 1993). The "agro-elite" confiscated land and used coerced labor to expand coffee for export, what Brockett refers to as "the repressive agro-export development model” (1991:37). The agro-export focus of coffee replicated the previous mineral export model by curtailing the rights of the peasantry and assimilating them as cheap labor or forcing them ever further into isolated peasant enclaves in the highlands.

During the latter half of the twentieth century peasant unions arose to contest such oppressive agrarian relations, including access to land. While such contestation contributed to civil wars in the neighboring countries of Nicaragua, El Salvador, and Guatemala, the situation in Honduras was less inflammatory; partly due to more (but hardly completely) successful agrarian reforms and concessions granted to peasant groups (Brockett 1991; Durham 1979; Schulz and Schulz 1994). One result of such contestation can be seen in the Cloud Forest Law of 1987, which created protected areas in all highland forests over $1800 \mathrm{~m}$ in elevation but allowed residents to remain as long as no further forest clearance occurred (AFE-COHDEFOR, GTZ and GFA TERRA Systems 2002; Portillo 1997). Celaque National Park, with a core area of $159 \mathrm{~km}^{2}$ between 1800 and 2849m in elevation, was created out of this law, along with 35 other protected areas throughout Honduras.

Because of heavy state indebtedness resulting from the "lost decade" of development in the 1980s, international lenders forced Honduras to adopt sweeping neoliberal structural adjustment policies throughout the 1990s that decreased public spending and promoted the agroexport sector (Jansen 1998; Schulz and Schulz 1994). Concurrently, the 1992 General Law of the Environment 
formalized 107 protected areas covering 24\% of Honduran national territory (AFE-COHDEFOR, GTZ and GFA TERRA Systems 2002; Richards 1996). While creating a formal protected area system, the structural adjustments contradictorily applied fiscal restraints that denied adequate funding for the management of the system (Schelhas and Pfeffer 2008). To alleviate the funding mismatch, a 1993 Executive Agreement allowed the management of public protected areas by NGOs, community groups, corporations, or even individuals willing to fund conservation programs (Beltr'an and Esser 1999). Initially this appeared to decentralize conservation decisionmaking from the state to local interests, but in actuality the reverse occurred as control shifted from the state to international development agencies and associated foreign controlled NGOs.

The shift from state to international control occurred in the Celaque Mountains as the German development agency GTZ, in conjunction with the Global Environment Facility’s Mesoamerican Biological Corridor Program, funded the US\$1.6 million Support to Cerro Celaque National Park Project in 1997 (GEF 1999; GTZ 2002). In the spirit of decentralization, a "local" NGO was created through which Celaque National Park would be managed. Called Proyecto Celaque, it was headed by a GTZ employee, also a German national, with the vast majority of its Honduran employees from regions of the country far removed from the Celaque Mountains, most notably the capital Tegucigalpa. The Proyecto Celaque team authored a park management based on the priorities of GEF funding and GTZ practices with the stated goal of promoting resident relocation (AFE-COHDEFOR, GTZ and GFA TERRA Systems 2002), a reversal of the 1987 Cloudforest Law policy. The change in management policies from a domestically sensitive one allowing for continual occupation to a global national park policy stressing exclusion was facilitated by the structural political economy of debt induced neoliberal reforms that promoted decentralization, resulting in the creation of a proxy "local" NGO through which to manage the park. 
While the park management plan instituted an exclusionary policy, Proyecto Celaque had no mandate to forcibly implement relocation of established settlements. But in 1998, just a year after the founding of Proyecto Celaque, Hurricane Mitch served the basic tenet of disaster capitalism by facilitating the implementation of this policy. With extensive flooding, loss of housing and food, and numerous deaths, the vulnerable affected residents of Celaque National Park sent emissaries to solicit help from the local municipality of San Manuel de Colohete for food, medicine, and reconstruction aid.

The mayor of the municipality originally offered assistance in the rebuilding of their original communities within the park, which initially exhibited the power of decentralization in including local decision-making in disaster recovery. However, in subsequent meetings between the municipality and Proyecto Celaque it was decided that assistance in rebuilding communities within the park would encourage continued habitation, conflicting with the newly stated goals of the park management plan, and the offer of in situ assistance was repealed (Oviedo 1999). Instead, the municipality, the local Catholic Church, Proyecto Celaque, and the United States based NGO Amigos de las Am'ericas offered assistance only to households that relocated to one of two resettlement areas outside of Celaque National Park's boundary. A vast majority of residents on the south-facing slopes, which received greater damage, chose to relocate while those on the northern slopes, which were partially shielded due to topography and suffered less damage, chose to remain and rebuild on their own. In all, estimates are that half of the park's residents “chose”-albeit under duress—-to relocate (Oviedo 1999).

This situation is not unique - there are numerous examples of relocations from protected areas creating, by some estimates, up to 10 million new "environmental refugees” worldwide (Geisler and de Sousa 2001). Yet there exists a lack of empirical data on the direct socio-economic changes 
resulting from expulsion (Brockington and Igoe 2006). In addition, many attempts to do so have resulted in simply exhibiting that people living around a national park tend to be poor, but say nothing about the park’s direct role in causing their poverty (Agrawal and Redford 2009; Curran et al 2009; Wilkie et al 2006). The following empirical case study addresses such a critique by documenting the livelihood changes resulting from relocation from a national park, and in the process serves as an example of a new form of disaster capitalism tied to "neoliberal conservation" (Igoe and Brockington 2007:432).

\section{Empirical Repercussions of Relocation}

Stemming from the contextual situation of coerced relocation, the author undertook field research in the summers of 2002 and 2004 to assess changes in livelihoods related to access to land, intensity of land use, and income earning activities. Fieldwork in 2002 included initial site visits, preliminary discussions with Proyecto Celaque and peasant community members, and the acquisition of a secondary dataset on land use and livelihood activities prior to relocation that was compiled by Proyecto Celaque during relocation (Oviedo 1999). Fieldwork in 2004 consisted of open-ended household interviews and formal questionnaire surveys on land use and incomeearning activities, with results of prior land use and livelihood activities cross-checked for validity with the secondary dataset acquired from Proyecto Celaque. In all, 49 of the 61 relocated households were included in the survey and interviews.

The results exhibited the creation of land scarcity due to relocation, with a dramatic $70.2 \%$ reduction in access to land (see Table 1). Qualitatively the soils in the resettlement areas were reported to be worse or much worse by $89.8 \%$ of the households. Further, animal husbandry ceased and agrodiversity was reduced as households focused on a smaller number of basic crop staples. The decrease in access to quality land led to the abandonment of the traditional fallow 
system and, hence, the associated ecological services in maintaining soil fertility and controlling pests and weeds. To compensate, households increased the use of purchased fertilizers and adopted biocides, reflecting an intensification of agricultural production.

In turn, the costs attributable to the intensification of production increased reliance on incomeearning activities to meet household subsistence needs (see Tables 2 and 3). However, the diversity of income-earning activities decreased as market sales of animals and crops were abandoned and craft production ceased due to the physical separation from the natural soil resources required for the production of roofing tiles and pottery. In the place of a diversity of income-earning activities, wage labor essentially became the sole source of income for the relocated households (with only two exceptions).

[Insert Table 1,2,3]

The most significant change was the growth, both in numbers and time, of familial labor engaging in wage labor on the coffee fincas. The increased semi-proletarian nature of the households created an even greater number of cheap laborers for both neighboring ladino farmers and the agro-export coffee industry, representing what Carmen Deere terms "superexploitation" of familial labor in face of increased impoverishment (in Faber 1993:74). Hence, relocation created land scarcity, the intensification of land use, and an almost complete dependence on wage labor to provide income to meet subsistence needs.

Yet beyond the quantitative numbers and political ecology analysis of the structural forces responsible for these livelihood changes, lie the tangible impacts impoverishment has on the affected populace. Household members consistently claimed it had become much harder to meet their subsistence needs, and they lamented their "decision” to relocate. When asked if they would return to their original communities in the mountains if given the chance, all but one of 
the households responded affirmatively. The vast majority expressed great displeasure with the assistance they had received from Proyecto Celaque, as evident in the author initially being barred from the communities by angry residents until his credentials as a researcher, and not an employee of Proyecto Celaque, were confirmed. This does not bode well for winning community support for conservation; as one resident stated, "I love the mountains, but I hate the park."

Environmental Conservation through Disaster Capitalism The impoverishment of relocated peasant households from a national park is significant in its own right. Yet it also serves as an example of disaster capitalism whereby the shock created by a catastrophe is used to serve ulterior capitalist motives (Klein 2007; Schuller 2008). As evident in the case study of relocation from Celaque National Park, the devastation of Hurricane Mitch was used as an "oportunidad" to implement a policy of exclusionary nature protection derived from the American national park model (Oviedo 1999:1). The primitive accumulation of land from the peasantry resulted in land scarcity for the relocated households, which became increasingly engaged in the larger capitalist economic system through intensified agricultural production, the workings of formal land markets, and an increase in dependence on wage labor on capitalist farms. In effect, they became increasingly semi-proletarianized through the creation of land scarcity as capitalist relations of production expanded into the marginal periphery of the western highlands of Honduras.

The semi-proletarianization of the peasantry has long been observed in Central America where disarticulated economies have necessitated the creation of cheap labor to serve the interests of export industries (Brockett 1991; de Janvry 1981; Faber 1993). In contrast to articulated capitalist economies where rising production for the domestic market necessitates rising wages for consumption to meet the increased demand, disarticulated economies are defined by external 
linkages to produce cheap products for foreign demand (Faber 1993). Hence, there is a disincentive to raise wages since it only amounts to a loss for the capitalist as local markets are ignored. Since members of the semi-proletariat also produce part of their own subsistence through food production, wages can be kept below the cost of subsistence. When peasants become semi-proletarians and earn part of their subsistence through the wage labor process they create "surplus value in the orthodox Marxist sense as applied to capitalist production” (Ellis 1988:54). It is in this process that capitalism truly exploits peasants, yet at the same time ensures their survival in the disarticulated economies of peripheral regions through functional dualism (de Janvry 1981).

Traditionally the coerced (or forced) semi-proletarianization of the Central American peasantry has relied on repressive state policies to promote capitalist profit seeking. In this case a new strategy for primitive accumulation was utilized; the debt-imposed adoption of an exclusionary national park model implemented through disaster reconstruction. The increased semi-proletarian nature of the relocated peasants is reflected in the heightened dependence on wage labor for the export-oriented coffee industry (see Figure 1), which with the ending of the International Coffee Agreement in 1989 became an industry in crisis. The neoliberal ending of market regulation resulted in the flooding of coffee beans into the market that precipitated a collapse in coffee prices, in many cases below the cost of production (O’Brien and Kinnaird 2003; Talbot 2004; see also Figure 2). Without other recourse, the impoverished semi-proletarian laborers of the Celaque Mountains accepted lower piece-meal wages, which dropped from 15 Lempiras per bucket of coffee beans in 1997 to 10 Lempiras in 2003, at precisely the time when international coffee prices dropped to record lows (\$0.34 per pound in 2001), effectively buoying the struggling coffee producers through cheap labor (Timms 2007).

[Insert Figure 1, 2] 
Interestingly, research has shown that within the higher reaches of Celaque National Park, near the original resident communities, mature forest over 20 years old increased from $35.4 \%$ in 1987 to 57.3\% in 1998 as the Lenca peasants followed national park policy and allowed their secondary forest fallows to mature (Aguilar 2003). Hence, the original park policy allowing the residents to remain within the park without further forest clearance actually coincided with an increase in mature forests between the year of the park’s inception, 1987, and the year of relocation, 1998; a finding that clearly does not support the assumption that the residents were increasingly degrading the park’s forest cover.

Yet the park is suffering human-induced degradation and research has pointed to encroaching coffee fincas at lower elevations near, and within, the park's boundaries as the major threat (Southworth, Tucker and Monroe 2002). The transition of forest to coffee fincas has been reported as the major land cover change in nearby mountainous areas of western Honduras as well (Bass 2006; Cherrett 2001; Schelhas and Pfeffer 2008). Coffee production has been promoted in Honduras and, specifically in this case, Proyecto Celaque pointed to labor on fincas for the relocated population as an environmentally friendly alternative to their assumed degrading small farming systems within the park (AFE-COHDEFOR, GTZ and GFA TERRA Systems 2002). While shade grown coffee plantations have been promoted as bio-diverse agro-systems, when compared with the original forests they replace it represents significant degradation (O’Brien and Kinnaird 2003). Hence, the relocation of peasants from Celaque National Park resulted in labor conditions that contributed to the expansion of capitalist production methods of coffee production by converting forest to plantation, the main environmental threat to the park (Timms 2007).

The GTZ funding for the Proyecto Celaque ended in 2003 (GTZ 2004), and the NGO no longer exists. The local national park guard service set up by the NGO, the guardarecursos, were not 
informed of this development and they disbanded irritably when it became apparent that their salaries had not been paid in months. Most have now staked their futures on becoming tourist guides for the park, attending "tourism training" and competing for the trickle of budget backpackers who venture into this remote corner of the highlands of Honduras. Little institutional presence exists for managing the park and local tensions have even risen over collection of park entrance fees from visitors.

Coincidentally, building upon the "success" of Proyecto Celaque, a new GTZ-funded program titled the Protection and Economic Use of Natural Resources was initiated and disbursed $€ 3,850,000$ over the time period 2003-2007 with the goal of promoting sustainable development in the buffer zone surrounding Celaque National Park (GTZ 2004). While research to ascertain the impact of this program on local populations has yet to be done, it is evident that the resultant socio-economic repercussions of relocation served not only the capitalist interests of the agro-export coffee sector, but also became a fetish commodity for GTZ in attracting funding for further projects.

It may appear contradictory for organizations whose mantra is the protection of nature from human (and often capitalist-driven) degradation to be critiqued for employing disaster capitalism in the same breath as war profiteers; yet it is representative of the remaking of humanenvironment relationships in the neoliberal era (Mansfield 2007), with disruptive social, economic, and environmental ramifications. The designation of protected areas managed by NGOs for communal or public lands is, in effect, privatization and forms the basis of primitive accumulation and dispossession. Further, the use of the effects of shock from a disaster to implement this form of primitive accumulation, and the change in the relations of production this 
entails, expands capitalism into new frontiers. As such, the work of Proyecto Celaque exhibits David Harvey’s assertion that NGOs are “Trojan horses for global neoliberalism” (2005:177).

\section{Concluding Thoughts}

In this paper disaster capitalism has been applied to a new context; environmental conservation. The implementation of the global national park model is criticized for its' universal model which seeks to protect nature from human activity by fencing it in and excluding human occupation. The diffusion of the national park model globally has been facilitated by unequal power relations exercised through the neoliberal political economy structure of debt, which transfers power from local or state control to global interests. However, in the case of Celaque National Park it took a natural disaster, Hurricane Mitch, to provide the opportunity to coercively implement exclusionary policies. In effect, exclusionary nature protection served as a powerful vehicle for primitive accumulation creating conditions of land scarcity, semi-proletarianization of the peasantry, and facilitating the expansion of capitalist social relations of production in the marginal peripheries of the world while becoming a fetish commodity for international conservation organizations (Brockington, Duffy and Igoe 2008).

The most troubling aspect is the use, or misuse, of a shock such as hurricane destruction that makes victims "psychologically unmoored and physically uprooted" in order to circumvent democracy in reshaping society (Klein 2007:25). There is intent involved, which makes the resultant negative socio-economic and environmental repercussions ever the more ominous. For the affected residents with dead family members, destroyed homes, and no food or medicine there was little choice but to accept the conditional assistance in order to receive short-term relief; with resultant long-term relocation. The relocation of residents to provide assistance was argued as logistically necessary due to the difficult accessibility of the highland settlements within Celaque 
National Park (Oviedo 1999), an argument made moot by a missionary group that organized a mule-train to deliver food, medicine, clothing, and building materials to the damaged village of La Chimis. While located in the vicinity of other damaged villages where relocation became the recovery option, the households in La Chimis were able to rebuild with the relief supplies provided to them.

Religious groups obviously have their own agendas and motives, but the response of this particular group to provide in situ relief without conditions provides an example of humanitarian assistance based on the best interest of the local victims. Too often local participation consists merely of informing locals rather than including them in the process, leading to less than satisfactory strategies of development, conservation, and/or disaster recovery (Agrawal and Redford 2009; Comfort et al 1999; Lewis 1999; Wisner et al 2003). In this case, local pleas for rebuilding assistance were trumped by global environmental conservation interests for relocation, which should be a strategy of last resort.

The case of coerced relocation from Celaque National Park was not a strategy of last resort as the funding interests of environmental conservation organizations and the agro-export coffee industry were advanced over those of the victims. The relocated population became increasingly pauperized and, as a result, disenchanted with the concept of nature protection, which in the long term works against the goals of environmental conservation. In this regard, we must refocus the fundamental principle of disaster reconstruction on the best interests of those directly affected if we are to achieve less opportunistic and more sustainable human-environmental relations.

\section{Acknowledgements}

The research upon which this paper is based was funded by the Tinker Foundation and would not have been possible without the help of two Honduran field guides and the people of the Celaque 
Mountains. The author would like to thank Dennis Conway, Emilio Moran, Bill McConnell, Charles Greer and the three anonymous referees for their constructive contributions and reviews.

\section{References}

AFE-COHDEFOR, GTZ and GFA TERRA Systems (2002) Plan General de Manejo: Parque Nacional Montã na de Celaque. Santa Rosa de Copan, Honduras: Proyecto Celaque

Agrawal A and Gibson C C (1999) Enchantment and disenchantment: The role of community in natural resource conservation. World Development 27(4):629-649

Agrawal A and Redford K (2009) Conservation and displacement: An overview. Conservation and Society 7(1):1-10

Aguilar A (2003) "Spatial patterns and dynamics of forest regeneration in Celaque National Park, Honduras.” Unpublished PhD thesis, UCLA

Bass J O (2006) Forty years and more trees: Land cover change and coffee production in Honduras. Southeastern Geographer 46(1):51-65

Bebbington A (2004) NGOs and uneven development: Geographies of development intervention. Progress in Human Geography 28(6):725-745

Beltr'an J and Esser J (1999) Protected Area Management: Analysis of the Contribution of NonPublic Sector to In Situ Biodiversity Conservation in Costa Rica, Honduras and Nicaragua, Central America. Eschborn, Germany: Deutsche Gesellschaft f"ur Technische Zusammenarbeit (GTZ)

Brady S (2003) Guachipilines and cercos zanjos: Lenca land use in the Guajiquiro Biological Reserve. In M K Steinberg and P F Hudson (eds) Cultural and Physical Expositions: Geographic Studies in the Southern United States and Latin America (pp 59-71). Baton Rouge, LA: Geoscience Publications 
Brockett C D (1991) Land, Power, and Poverty: Agrarian Transformation and Political Conflict in Central America, 1st ed. Boulder, CO: Westview Press

Brockington D and Igoe J (2006) Eviction for conservation: A global overview. Conservation and Society 4(3):424-470

Brockington D, Igoe J and Schmidt-Soltau K (2006) Conservation, human rights, and poverty reduction. Conservation Biology 20(1):250-252

Brockington D, Duffy R and Igoe J (2008) Nature Unbound: Conservation, Capitalism and the Future of Protected Areas. London: Earthscan

Burnham P (2000) Indian Country, God's Country: Native Americans and the National Parks. Washington, DC: Island Press

Carr E (1998) Wilderness by Design: Landscape Architecture and the National Park Service. Lincoln, NB: University of Nebraska Press

Carrier J and Macleod D V L (2005) Bursting the bubble: The socio-cultural context of ecotourism. Royal Anthropological Institute 11:315-334

Chape S, Blyth S, Fish L, Fox P and Spalding M (compilers) (2003) 2003 United Nations List of Protected Areas. Cambridge, UK: IUCN and UNEP-WCMC

Chapin M (2004) A challenge to conservationists. World Watch November/ December:17-31

Cherrett I (2001) Decentralization, rural poverty, and degradation of uplands in Central America. Mountain Research and Development 21(3):221-225

Comfort L, Wisner B, Cutter S, Pulwarty R, Hewitt K, Oliver-Smith A, Wiener J, Forham M, Peacock W and Krimgold F (1999) Reframing disaster policy: The global evolution of vulnerable communities. Environmental Hazards 1:39-44 
Conway D and Timms B (2003) Where is the environment in Caribbean development theory and praxis? Global Development Studies 3(1-2):91-130

Cosgrove D E (1985) Social Formation and Symbolic Landscape. Totowa, NJ: Barnes \& Noble Books

Curran B, Sunderland T, Maisels F, Oats J, Asaha S, Balinga M, Defo L, Dunn A, Telfer P, Usongo L, von Loebenstein K and Roth P (2009). Are Central Africa's protected areas displacing hundreds of thousands of rural poor? Conservation and Society 7(1):30-45

Davey A G (1998) National System for Protected Areas. Cambridge, UK: IUCN

de Janvry A (1981) The Agrarian Question and Reformism in Latin America. Baltimore: The John Hopkins University Press

Dowie M (2009) Conservation Refugees: The Hundred-Year Conflict between Global Conservation and Native Peoples. Cambridge: The MIT Press

Durham W H (1979) Scarcity and Survival in Central America: Ecological Origins of the Soccer War. Palo Alto, CA: Stanford University Press

Ellis F (1988) Peasant Economies: Farm Households and Agrarian Development. Cambridge, UK: Cambridge University Press

Escobar A (1995) Encountering Development: The Making and Unmaking of the Third World. Princeton, NJ: Princeton University Press

Faber D (1993) Environment Under Fire: Imperialism and the Ecological Crisis in Central America. New York: Monthly Review Press

Finney K V (1978) Rosario and the election of 1887: The political economy of mining in Honduras. The Hispanic American Historical Review 59(1):81-107 
Geisler C and de Sousa R (2001) From refuge to refuge: The African case. Public Administration and Development 21:159-170

Germic S (2001) American Green: Class, Crisis, and the Deployment of Nature in Central Park, Yosemite, and Yellowstone. Lanham, MD: Lexington Books

Giroux H (2006) Stormy Weather: Katrina and the Politics of Disposability. Boulder: Paradigm Publishers

Global Environment Facility (GEF) (1999) Project Document: Establishment of a Programme for the Consolidation of the Mesoamerican Biological Corridor. New York: United Nations Development Programme

Grove R H (1995) Green Imperialism: Colonial Expansion, Tropical Island Edens and the Origins ofEnvironmentalism,1600-1860. Cambridge, UK: Cambridge University Press

Grusin R (1998) Reproducing Yosemite: Olmsted, environmentalism, and the nature of aesthetic agency. Cultural Studies 12(3):332-359

GTZ (2002) Biodiversity in German Development Cooperation, 4th ed. Eschborn, Germany: Deutsche Gesellschaft f"ur Technische Zusammenarbeit GTZ (2004) Biodiversity in German Development Cooperation, 5th ed. Eschborn, Germany: Deutsche Gesellschaft f"ur Technische Zusammenarbeit Gunewardena N (2008) Peddling paradise, rebuilding Serendib: The 100-meter refugees versus the tourism industry in post-tsunami Sri Lanka. In N Gunewardena and M Schuller (eds) Capitalizing on Catastrophe: Neoliberal Strategies in Disaster Reconstruction (pp 69-92). Lanham, MD: Altamira Press 
Harvey D (2005) A Brief History of Neoliberalism. New York: Oxford University Press Igoe J and Brockington D (2007) Neoliberal conservation: A brief introduction. Conservation and Society 5(4):432-449

IUCN (2009) The IUCN Red List of Threatened Species. http://www.iucnredlist.org (last accessed 17 March 2010)

Jacoby K (2001) Crimes Against Nature: Squatters, Poachers, Thieves, and the Hidden History of American Conservation. Berkeley: University of California Press

Jansen K (1998) Political Ecology, Mountain Agriculture, and Knowledge in Honduras. Amsterdam: Thela Publishers

Katz C (1998) Whose nature, whose culture? Private productions of space and the "preservation” of nature. In B Braun and N Castree (eds) Remaking Reality: Nature at the Millenium (pp 4663). London: Routledge Press

Klein N (2007) The Shock Doctrine: The Rise ofDisaster Capitalism. New York: Picador Krueger L (2009) Protected areas and human displacement: Improving the interface between policy and practice. Conservation and Society 7(1):21-25

Lehmann C (2001) Of dams and hurricanes: Lessons and recommendations from El Cajon. Mountain Research and Development 21(1):10-13

Lewis J (1999) Development in Disaster-Prone Places: Studies of Vulnerability. London: IT Books

Mansfield B (2007) Privatization: Property and the remaking of nature-society relations: Introduction to the special issue. Antipode 39(3):393-405 
Mbembe A (2001) On the Postcolony. Berkeley: University of California Press Michael M A (1995) International justice and wilderness preservation. Social Theory and Practice 21(2):149177

Morris S S and Wodon Q (2003) The allocation of disaster relief funds: Hurricane Mitch in Honduras. World Development 31(7):1279-1289

NACLA (1999) Central America after Mitch. NACLA Report on the Americas XXXIII(2):10

Neumann R P (1998) Imposing Wilderness: Struggles over Livelihood and Nature Preservation in Africa. Berkeley: University of California Press

Newson L (1982) Labour in the colonial mining industry of Honduras. The Americas 39(2):185203

O’Brien T and Kinnaird M F (2003) Caffeine and conservation. Science 300(5619): 587

Oliver-Smith A (ed) (1986) Natural Disasters and Cultural Responses: Studies in Third World Societies Number 36. Williamsburg, VA: College of William and Mary Press Ostrom E (1990) Governing the Commons: The Evolution of Institutions for Collective Action. Cambridge: Cambridge University Press

Oviedo M I (1999) Informe-Diagnostico Sobre la Situacion de las Familias Reubicada en la Zona de Amortiguamiento del Parque Nacional Celaque. Santa Rosa de Copan, Honduras: Proyecto Celaque

Patin T (1999) Exhibitions and empire: National parks and the performance of manifest destiny. Journal of American Culture 22(1):41-59

Peluso N L and Watts M (2001) Violent environments. In N L Peluso and M Watts (eds) Violent Environments (pp 3-38). Ithaca, NY: Cornell University Press 
Petras J and Veltmeyer H (2002) The peasantry and the state in Latin America: A troubled past, an uncertain future. Journal of Peasant Studies 29(3):41-82

Portillo N P (1997) Geograf'ıa de Honduras, 3rd ed. Tegucigalpa, Honduras: Colonia Miraflores Powers M P (2006) A matter of choice: Historical lessons for disaster recovery. In C Hartman and G D Squires (eds) There is No Such Thing as a Natural Disaster: Race, Class, and Hurricane Katrina (pp 13-36). New York: Routledge

Reice S R (2003) The Silver Lining: The Benefits of Natural Disasters. Princeton, NJ: Princeton University Press

Ribot J C (2004) Waiting for Democracy: The Politics of Choice in Natural Resource Decentralizations. Washington: World Resources Institute

Richards M (1996) Protected areas, people and incentives in the search for sustainable forest conservation in Honduras. Environmental Conservation 23(3):207- 217

Romero C and Andrade G I (2004) International conservation organizations and the fate of local tropical forest conservation initiatives. Conservation Biology 18(2):578-580 Russell G (1999) Hurricane Mitch and human rights. Development in Practice 9(3):322-

325

Schelhas J and Pfeffer M J (2008) Saving Forests, Protecting People? Environmental Conservation in Central America. Plymouth, UK: AltaMira Press

Schuller M (2008) Deconstructing the disaster after the disaster: Conceptualizing disaster capitalism. In N Gunewardena and M Schuller (eds) Capitalizing on Catastrophe: Neoliberal Strategies in Disaster Reconstruction (pp 17-27). Lanham, MD: Altamira Press

Schulz D E and Schulz D S (1994) The United States, Honduras, and the Crisis in Central America. Boulder, CO: Westview Press 
Scott J C (1985) Weapons of the Weak: Everyday Forms of Peasant Resistance. New Haven: Yale University Press

Smethurst D (2000) Mountain Geography. The Geographical Review 90(1):35-56

Southworth J, Tucker C and Munroe D (2002) The dynamics of land-cover change in western Honduras: Exploring spatial and temporal complexity. Agricultural Economics 27:355-369

Spence M D (1999) Dispossessing the Wilderness: Indian Removal and the Making of the National Parks. Oxford: Oxford University Press

Stonich S (1993) I am Destroying the Land! The Political Ecology of Poverty and Environmental Destruction in Honduras. Boulder, CO: Westview Press

Stonich S (2008) International tourism and disaster capitalism: The case of Hurricane Mitch in Honduras. In N Gunewardena and M Schuller (eds) Capitalizing on Catastrophe: Neoliberal Strategies in Disaster Reconstruction (pp 47-68). Lanham, MD: Altamira Press

Talbot J M (2004) Grounds for Agreement: The Political Economy of the Coffee Commodity Chain. Lanham, MD: Rowman \& Littlefield Publishers

Timms B (2007) "Renegotiating Peasant Ecology: Responses to Relocation from Celaque National Park, Honduras.” Unpublished PhD thesis, Indiana University

Timms B (2008) The parallax of landscape: Situating Celaque National Park, Honduras. In D Knudsen, M Metro-Roland, A Soper and C Greer (eds) Landscape, Tourism, and Meaning (pp 95-108). Aldershot, UK: Ashgate Publishing

Tsing A L (2005) Friction: An Ethnography of Global Connection. Princeton: Princeton University Press 
West R C (1958) The Lenca Indians of Honduras: A study in ethnogeography. In R C West (ed) Latin American Geography: Historical-Geographical Essays, 1941-1998 (pp 67-76). Baton Rouge, LA: Geoscience Publications

White G (ed) (1974) Natural Hazards: Local, National, Global. New York: Oxford University Press

Wilkie D S, Morelli G A, Demmer J, Starkey M, Telfer P and Steil M (2006) Parks and people: Assessing the human welfare effects of establishing protected areas for biodiversity donservation. Conservation Biology 20(1):247-249

Wilshusen P R, Brechnin S R, Fortwangler C L and West P C (2002) Reinventing a square wheel: Critique of a resurgent "Protection Paradigm” in international biodiversity donservation. Society and Natural Resources 15:17-40

Wisner B, Blaikie P, Cannon T and Davis I (2003) At Risk: Natural Hazards, People's Vulnerability and Disasters, 2nd ed. London: Routledge

World Conservation Monitoring Centre (WCMC) (1998) Workshop Report: Tropical Montane Cloud Forests Planning and Advisory Workshop, July 1998. Cambridge, UK: World Conservation Monitoring Centre

Zimmerer K S (2006) Geographical perspectives on globalization and environmental issues: The inner-connections of conservation, agriculture, and livelihoods. In K S Zimmerer (ed) Globalization \& New Geographies of Conservation (pp 1-43). Chicago: University of Chicago Press 
Table 1: Selected summary data on land-use changes

\begin{tabular}{lcc}
\hline & Pre-relocation & Post-relocation \\
\hline Land owned (ha) per household & 4.16 & 1.24 \\
Number of land parcels per household & 1.02 & 1.63 \\
Percent of land cultivated per household & 66.7 & 88.3 \\
Number of livestock per household & 2.53 & 0.35 \\
Number of crop types per household & 6.45 & 4.04 \\
Percent of household purchasing fertilizer & 61.2 & 98.0 \\
Percent of household purchasing biocides* & 0.0 & 36.7 \\
\hline
\end{tabular}

${ }^{*}$ Includes pesticides and herbicides

Table 2: Number of households engaged in income-earning activities

\begin{tabular}{lcc}
\hline & Pre-relocation & Post-relocation \\
\hline Labor on coffee fincas & 49 & 49 \\
Production and sale of produce at market & 35 & 1 \\
Raising and sale of animals at market & 12 & 0 \\
Production and sale of pottery & 7 & 0 \\
Production and sale of roofing tiles & 5 & 0 \\
Labor on ladino farms & 0 & 13 \\
Operate a pulperia* & 0 & 1 \\
\hline
\end{tabular}

*A pulperia is a basic goods store supplying the local community.

Table 3: Selected summary data on changes in income-earning activities

\begin{tabular}{lcc}
\hline & Pre-relocation & Post-relocation \\
\hline Income-earning activities per household & 2.25 & 1.43 \\
Percent of households selling animals & 50.0 & 0.0 \\
Percent of households selling produce & 71.4 & 2.0 \\
Household members laboring on coffee fincas & 1.88 & 4.71 \\
Annual weeks laboring on coffee fincas & 2.33 & 7.12 \\
\hline
\end{tabular}

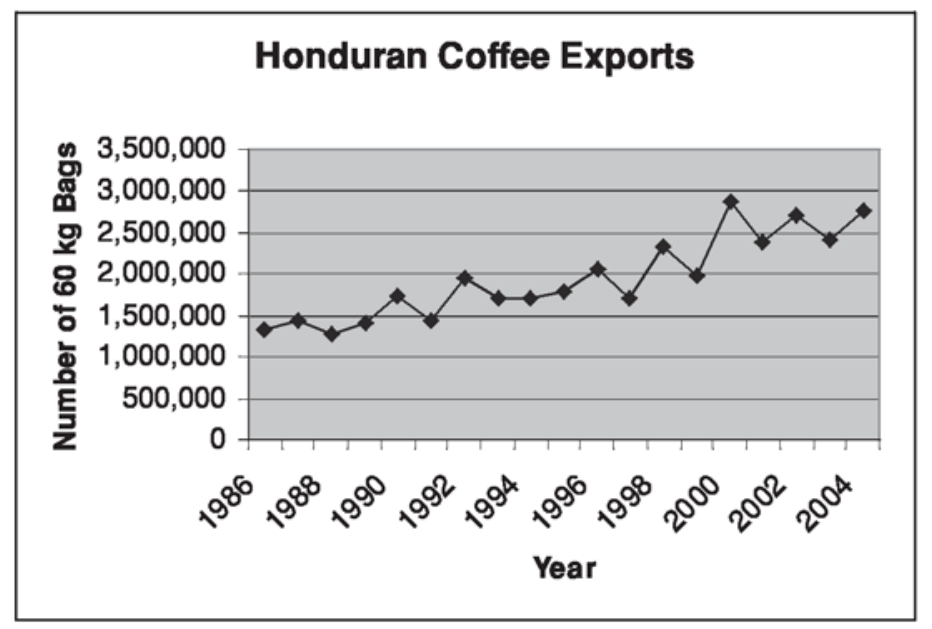

Figure 1: Honduran Coffee Exports, 1986-2004

(Data Source: ICO 2005) 


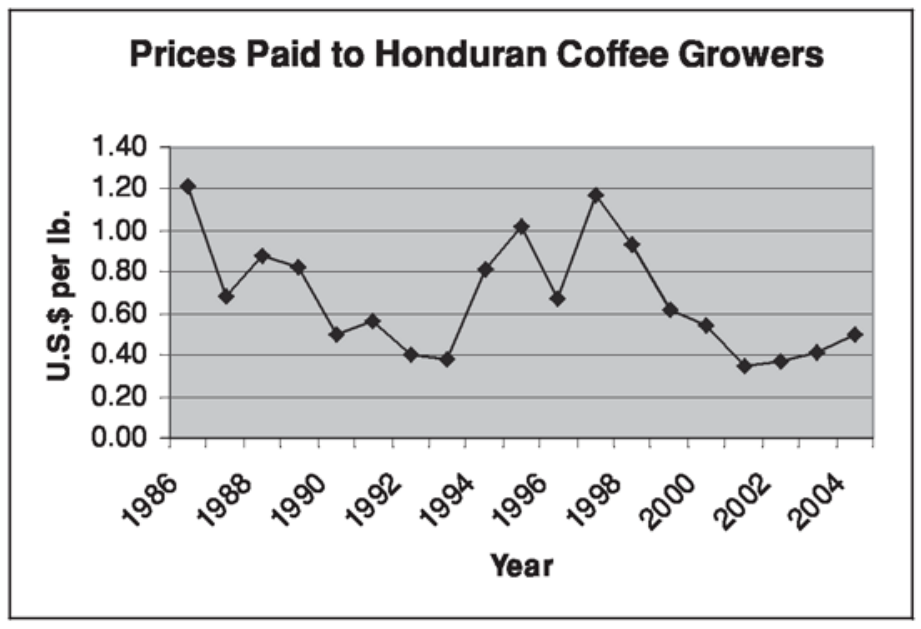

Figure 2: Prices Paid to Honduran Coffee Growers, 1986-2004 (Data Source: ICO 2005) 